\title{
Black carbon concentrations and sources in the marine boundary layer of the tropical Atlantic Ocean using four methodologies
}

\author{
K. Pohl ${ }^{1}$, M. Cantwell ${ }^{2}$, P. Herckes ${ }^{3}$, and R. Lohmann ${ }^{1}$ \\ ${ }^{1}$ Graduate School of Oceanography-University of Rhode Island, Narragansett, RI, USA \\ ${ }^{2}$ Environmental Protection Agency-Atlantic Ecology Division, Narragansett, RI, USA \\ ${ }^{3}$ Department of Chemistry and Biochemistry, Arizona State University, Tempe, AZ, USA \\ Correspondence to: R. Lohmann (rlohmann@mail.uri.edu)
}

Received: 19 September 2013 - Published in Atmos. Chem. Phys. Discuss.: 13 November 2013

Revised: 3 June 2014 - Accepted: 10 June 2014 - Published: 18 July 2014

\begin{abstract}
Combustion-derived aerosols in the marine boundary layer have been poorly studied, especially in remote environments such as the open Atlantic Ocean. The tropical Atlantic has the potential to contain a high concentration of aerosols, such as black carbon, due to the African emission plume of biomass and agricultural burning products. Atmospheric particulate matter samples across the tropical Atlantic boundary layer were collected in the summer of 2010 during the southern hemispheric dry season when open fire events were frequent in Africa and South America. The highest black carbon concentrations were detected in the Caribbean Sea and within the African plume, with a regional average of $0.6 \mu \mathrm{g} \mathrm{m}^{-3}$ for both. The lowest average concentrations were measured off the coast of South America at 0.2 to $0.3 \mu \mathrm{g} \mathrm{m}^{-3}$. Samples were quantified for black carbon using multiple methods to provide insights into the form and stability of the carbonaceous aerosols (i.e., thermally unstable organic carbon, soot like, and charcoal like). Soot-like aerosols composed up to $45 \%$ of the carbonaceous aerosols in the Caribbean Sea to as little as $4 \%$ within the African plume. Charcoal-like aerosols composed up to $29 \%$ of the carbonaceous aerosols over the oligotrophic Sargasso Sea, suggesting that non-soot-like particles could be present in significant concentrations in remote environments. To better apportion concentrations and forms of black carbon, multiple detection methods should be used, particularly in regions impacted by biomass burning emissions.
\end{abstract}

\section{Introduction}

Black carbon (BC) is the byproduct of the incomplete combustion of biomass and fossil fuels that is composed of highly condensed matrices of aromatic sheets (Goldberg, 1985). It has the potential for long range atmospheric transport which makes it ubiquitous in the environment (Ogren and Charlson, 1983; Chuang et al., 2002; Masiello, 2004). Atmospheric BC is an important forcing factor with respect to climate change, second only to carbon dioxide (Husain et al., 2007; Bond et al., 2013; Novakov and Rosen, 2013). Its optical properties make it a strong absorber of incident sunlight and its deposition to the ocean is a potential long-term sink for fixed carbon and organic pollutants (Schmidt and Noack, 2000; Forbes et al., 2006). Black carbon is rarely measured in remote environments causing aerosol models, such as MOGUNTIA, NCAR GM3, GISS ModelE, and ECHAM5-HAM-OM1, to deal with significant uncertainty in ground truthing their predictions (Lohmann et al., 2009). Instead, results are often extrapolated to estimate $\mathrm{BC}$ concentrations in these remote regions. This uncertainty is further exacerbated by the fact that $\mathrm{BC}$ results are operationally defined by the selected analytical method (Schmidt et al., 2001; Andreae and Gelencser, 2006).

Combustion-derived aerosols in the marine boundary layer have been poorly investigated. Field investigations in the North Atlantic have determined that a "clean air" background concentration of black carbon ranges from 20 to $40 \mathrm{ng} \mathrm{m}^{-3}$, demonstrating that black carbon is ubiquitous even in remote marine systems (Cavalli et al., 2004; O’Dowd et al., 2004). Peak concentrations of black carbon in the remote marine 
boundary layer have been reported up to $600 \mathrm{ng} \mathrm{m}^{-3}$ in the Azores (summertime) and $300 \mathrm{ng} \mathrm{m}^{-3}$ in the Indian Ocean (Corrigan et al., 2008; Spracklen et al., 2008). The tropical Atlantic Ocean has the potential to contain even greater BC concentrations due to the intense emission plume originating from equatorial Africa. Simulations from the NCAR GM3 model coupled to IMPACT have projected that one of the strongest anthropogenic surface $\mathrm{BC}$ signals is confined inbetween 0 and $40^{\circ} \mathrm{N}$ as a result of African biomass and fossil fuel emissions (Liu et al., 2009).

The subtropical Atlantic Ocean is expected to have elevated $\mathrm{BC}$ concentrations due to this African emission plume, which is a combination of intense grassland and agricultural burning transported off-shore by easterly winds (Chester et al., 1979; Perry et al., 1997; Bond et al., 2004; Ramanathan and Carmichael, 2008; Koch et al., 2009; Lohmann et al., 2009). High concentrations of water soluble biomass burning products created by this intercontinental plume, which can be seen in satellite images, are horizontally ejected into the planetary boundary layer below $6 \mathrm{~km}$ (Talbot et al., 1986). Model simulations by the LMD GCM model have predicted that the residence time of $\mathrm{BC}$ aerosols generated from Africa is approximately 7 days compared to 5 days from South America, representing $10 \%$ and $6 \%$ of the global mean BC emissions, respectively (Reddy and Boucher, 2007). This emission plume has the potential to contain high concentrations of fire-derived aerosols with atmospheric residence times sufficient for significant remote marine boundary layer concentrations.

Analytical methods to measure $\mathrm{BC}$ are classified into numerous different approaches: light absorption, thermal radiation, thermal carbon evolution, Raman Spectroscopy, and mircoscopy, with some hybridization of these approaches (Schmidt and Noack, 2000; Currie et al., 2002; Petzold et al., 2013). Black carbon is composed of various forms classified by its thermal recalcitrance, ranging from less stable charcoal to the highly refractory soot (Masiello, 2004; Elmquist et al., 2006). Charcoal is the solid combustion residue that retains some cellular characteristics of its parent material (Schmidt and Noack, 2000). It will be oxidized when exposed to a significant combination of heat and oxygen, thus methods that utilize high-temperature combustion to isolate $\mathrm{BC}$ will result in a loss of charcoal (Forbes et al., 2006). Soot particles are formed by the re-condensation of volatiles during combustion. Generally, soot is smaller than charcoal (typically $<1 \mu \mathrm{m}$ ), thus is expected to be a dominant fraction in remote environments due to enhanced export (Andreae et al., 1983; Masiello, 2004; Lohmann et al., 2009). However, micro-charcoal has been found and well studied in deep sediment cores. It is often used as a paleo-fire proxy for ecosystem reconstructions (Verardo and Ruddiman, 1996; Hoetzel et al., 2013).

The application of multiple BC analytical methods, such as chemothermal oxidation, thermal optical transmittance, pyrene fluorescence loss, and optical transmission attenua- tion, offers unique insights into the form and spatial trend of the various components of the $\mathrm{BC}$ combustion continuum (Masiello, 2004). The BC combustion continuum implies that $\mathrm{BC}$ is an operational definition of various forms of carbonaceous combustion byproducts that are classified by formation temperature, size, reactivity, and remnants of original organic material. It ranges from the solid residues of combustion termed charcoal to the re-condensed volatile aromatic structures termed soot. A multi-analytical approach is optimal in determining the fraction of soot-like and charcoallike combustion-derived aerosols in poorly studied regions, such as the tropical Atlantic. Both the chemothermal oxidation and thermal optical transmittance methods evolve the less refractory carbon constituents; the remaining carbon quantified is termed elemental carbon (Zencak et al., 2007; Gustafsson et al., 2009). Elemental carbon consists of highly reduced, graphitic-like, combustion-derived aerosols that is methodologically defined as a structure that will be oxidized at temperatures upward to $\sim 800^{\circ} \mathrm{C}$ (Birch and Cary, 1996; Lavanchy et al., 1999; Sharma et al., 2004; Park et al., 2006; Chow et al., 2009; Dutkiewicz et al., 2009). The pyrene fluorescence loss and optical transmission attenuation methods do not use gas evolution to isolate the refractory combustion-derived aerosols, thus have the potential to measure less stable combustion-derived aerosols, such as charcoal and macromolecular organics (Flores-Cervantes et al., 2009).

We hypothesize that (1) black carbon would be elevated in the tropical Atlantic boundary layer compared to other remote environments due to the African emission plume, (2) soot would be the dominant fraction of black carbon, and (3) the use of multiple methods would enable us to assess the relative proportions of the combustion-derived aerosols present (i.e., charcoal-like versus soot-like aerosols).

\section{Materials and methods}

\subsection{Sample collection}

A high-volume air sampler (Tisch Environmental Model TEPNY1123) was used to collect total suspended particulate samples on QM-A quartz fiber filters (QFF) on the $R / V$ Endeavor cruises EN-479 to EN-482 during the summer (July-August) of 2010 (Table 1). Filters were precombusted $\left(450{ }^{\circ} \mathrm{C}\right)$ before use and stored in precombusted aluminum foil in a freezer at $-10^{\circ} \mathrm{C}$. An average of $500 \mathrm{~m}^{3}$ of air was filtered per QFF at a flow rate of $0.42 \mathrm{~m}^{3} \mathrm{~min}^{-1}$ for QFF 112 and thereafter an average air volume of $3860 \mathrm{~m}^{3}$ at a flow rate of $1.35 \mathrm{~m}^{3} \mathrm{~min}^{-1}$ was filtered when we adjusted the flow to increase the sample size. Each filter sampled for approximately $20 \mathrm{~h}$ (QFFs 1-12) and $48 \mathrm{~h}$ (QFFs 13-24) and had an exposed area of $414 \mathrm{~cm}^{2}$. Sampling was conducted when we were underway and was stopped when wind direction blew exhaust towards our sampler and during stationary periods. 
Table 1. Sampling dates, volumes, coordinates, and total distance for each samples collected. Regional abbreviations as CS (Caribbean Sea), SA (South America), AP (African plume), and SubAt (subtropical Atlantic) were used.

\begin{tabular}{|c|c|c|c|c|c|c|c|c|c|}
\hline \multirow[b]{2}{*}{ Sample } & \multirow[b]{2}{*}{ Region } & \multirow{2}{*}{$\begin{array}{r}\text { (2010) } \\
\text { Start collect }\end{array}$} & \multirow{2}{*}{$\begin{array}{r}\text { (min) } \\
\text { Sample time }\end{array}$} & \multirow{2}{*}{$\begin{array}{r}\left(\mathrm{m}^{3}\right) \\
\text { Volume }\end{array}$} & \multicolumn{2}{|c|}{ Start } & \multicolumn{2}{|c|}{ End } & \multirow{2}{*}{$\begin{array}{r}(\mathrm{km}) \\
\text { Distance }\end{array}$} \\
\hline & & & & & Latitude & Longitude & Latitude & Longitude & \\
\hline 1 & CS & 6 July & 721 & 408 & 22.136 & -77.483 & 20.983 & -74.988 & 288 \\
\hline 2 & CS & 7 July & 725 & 308 & 20.983 & -74.988 & 20.021 & -70.654 & 464 \\
\hline 3 & $\mathrm{CS}$ & 7 July & 684 & 97 & 20.021 & -70.654 & 19.285 & -68.575 & 233 \\
\hline 4 & $\mathrm{CS}$ & 8 July & 737 & 104 & 19.285 & -68.575 & 17.615 & -67.033 & 246 \\
\hline 5 & $\mathrm{CS}$ & 8 July & 707 & 100 & 17.615 & -67.033 & 16.550 & -65.483 & 203 \\
\hline 6 & CS & 9 July & 741 & 315 & 16.550 & -65.483 & 15.416 & -63.783 & 221 \\
\hline 7 & $\mathrm{CS}$ & 9 July & 708 & 301 & 15.416 & -63.783 & 14.338 & -62.223 & 206 \\
\hline 8 & CS & 10 July & 691 & 294 & 14.338 & -62.223 & 13.453 & -60.817 & 181 \\
\hline 9 & $\mathrm{CS} / \mathrm{SA}$ & 14 July & 2823 & 1199 & 13.453 & -60.817 & 7.079 & -49.156 & 1458 \\
\hline 10 & $\mathrm{SA}$ & 16 July & 2455 & 1043 & 7.079 & -49.156 & 5.906 & -45.011 & 476 \\
\hline 11 & $\mathrm{CS}$ & 20 July & 2884 & 1225 & 5.906 & -45.011 & 11.179 & -55.835 & 1326 \\
\hline 12 & $\mathrm{CS}$ & 22 July & 1420 & 603 & 11.179 & -55.835 & 13.100 & -59.650 & 466 \\
\hline 13 & $\mathrm{CS}$ & 23 July & 2794 & 3758 & 13.100 & -59.650 & 9.483 & -51.266 & 989 \\
\hline 14 & $\mathrm{SA}$ & 27 July & 3287 & 4421 & 9.483 & -51.266 & 4.600 & -46.200 & 778 \\
\hline 15 & $\mathrm{AP}$ & 30 July & 3983 & 5358 & 4.600 & -46.200 & 1.580 & -28.767 & 1966 \\
\hline 16 & $\mathrm{AP}$ & 3 August & 3353 & 4510 & 1.580 & -28.767 & 3.961 & -21.667 & 832 \\
\hline 17 & $\mathrm{AP}$ & 6 August & 4532 & 6096 & 3.961 & -21.667 & 4.977 & -21.215 & 123 \\
\hline 18 & $\mathrm{AP}$ & 10 August & 2235 & 3006 & 4.977 & -21.215 & 4.554 & -24.496 & 367 \\
\hline 19 & $\mathrm{AP}$ & 15 August & 2209 & 2971 & 4.554 & -24.496 & 12.813 & -20.066 & 1035 \\
\hline 20 & SubAt & 21 August & 2682 & 3608 & 12.813 & -20.066 & 20.521 & -25.118 & 1009 \\
\hline 21 & SubAt & 23 August & 2718 & 3656 & 20.521 & -25.118 & 25.717 & -32.768 & 918 \\
\hline 22 & SubAt & 25 August & 2863 & 3851 & 25.717 & -32.768 & 30.167 & -41.027 & 950 \\
\hline 23 & SubAt & 27 August & 2846 & 3828 & 30.167 & -41.027 & 31.871 & -50.100 & 886 \\
\hline 24 & SubAt & 29 August & 943 & 1269 & 31.871 & -50.100 & 32.516 & -53.764 & 353 \\
\hline
\end{tabular}

After a sample was collected, filters were returned to the foil and freezer until analysis. Four laboratory blanks and two field blanks, of which $1 \mathrm{~m}^{3}$ of air was sampled, were also collected. We treated all blanks as samples.

Atmospheric BC samples were collected from four regions: the Caribbean Sea (QFF 1-9; QFF 11-13), South America (QFF 9-10; QFF 14), the African plume (QFF 1519), and the subtropical Atlantic (QFF 20-24). We note that QFF-9 was placed in both the Caribbean and South America since we had crossed the inter-tropical convergence zone during sampling (Table 1). The NOAA HYSPLIT (HYbrid Single-Particle Lagrangian Integrated Trajectory) model was used to estimate the wind backward trajectory $(20 \mathrm{~m})$ at the end time of each sample extending for ten days (Draxler and Rolph, 2013; Rolph, 2013; Fig. 1). Based on back trajectories, the inter-tropical convergence zone was around $10^{\circ} \mathrm{N}$.

\subsection{Chemothermal oxidation at $375^{\circ} \mathrm{C}(\mathrm{CTO}-375)$}

Duplicates of a $2.4 \mathrm{~cm}^{2}$ punch from each filter sample were acidified for $24 \mathrm{~h}$ with hydrochloric acid vapors to remove carbonate carbon. Filters were then oxidized in a Barnstead Thermolyne muffle oven at $375^{\circ} \mathrm{C}$ with a steady flow of high-purity air following the procedure by Gustafsson et al. (1997) and Gelinas et al. (2001). Samples were pelletized in $30 \mathrm{~mm}$ diameter tin discs then analyzed on a Carlo Erba elemental analyzer coupled to a GV Optima 588 system isotope ratio mass spectrometer (IR-MS) to determine carbon concentration and $\delta^{13} \mathrm{C}$ value. Total organic carbon (nonoxidized but acidified $2.4 \mathrm{~cm}^{2}$ filter punches) was also quantified. The detection limit for the instrument was $0.1 \mu \mathrm{g}$ of carbon. Carbon values quantified with the CTO-375 method will be denoted as $\mathrm{EC}_{\mathrm{CTO}}$.

\subsection{Thermal optical transmittance}

Samples were measured by the thermal optical transmittance (TOT) method for EC (EC $\mathrm{EOT}_{\text {T }}$ ) at Arizona State University. A thermal-optical instrument (Sunset laboratory TOT analyzer, NIOSH protocol) detects both the organic carbon and $\mathrm{EC}_{\text {TOT }}$ concentrations using one filter (adapted from Birch and Cary, 1996) and has a detection limit of $0.1 \mu \mathrm{g} \mathrm{cm}^{-2}$. Organic carbon was analyzed with varying time steps between $60 \mathrm{~s}$ and $200 \mathrm{~s}$ during the organic carbon evolution at $310,475,615$, and $870^{\circ} \mathrm{C}$ in an inert atmosphere. This was followed by the $\mathrm{EC}_{\text {TOT }}$ analysis with temperature profiles of $550,625,700,775$, and $850^{\circ} \mathrm{C}$ with a hold time of $45 \mathrm{~s}$ and a final hold at $870^{\circ} \mathrm{C}$ for $120 \mathrm{~s}$ in an oxidizing environment (Adapted from Birch and Carey, 1996). In the TOT method, any pyrolytic carbon formation is corrected by 


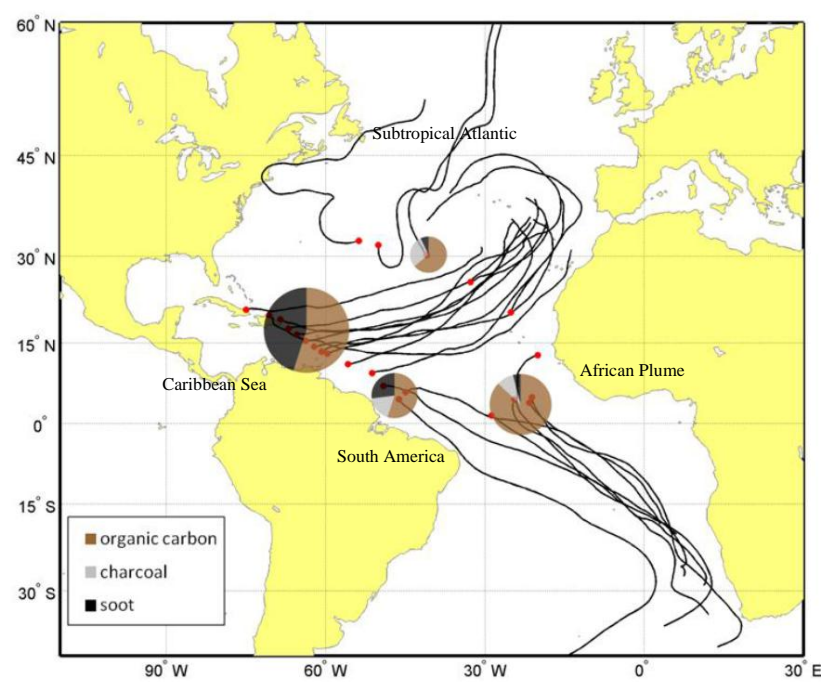

Figure 1. HySPLIT estimates of a 10-day backward wind trajectory at the end of each filter sample at a height of $20 \mathrm{~m}$ and the average regional fraction of black carbon within the total organic carbon (Mercator projection). Black carbon is further divided between thermally unstable organic carbon, soot (CTO-375), and charcoal (pyrene fluorescence loss). The size of each pie chart is in accordance to regional average total organic carbon concentration ranging from 0.2 to $1.8 \mu \mathrm{g} \mathrm{m}^{-3}$.

optical transmission measurements; however, in the present study no pyrolytic carbon formation was observed. Samples 1 and 22-24 were not quantified via TOT since filters shrank during analysis, suggesting they were glass filters. We will still refer to these samples as QFFs in text.

\subsection{Pyrene fluorescence loss}

The initial fluorescence of a $1 \mu \mathrm{g} \mathrm{L}-1$ aqueous pyrene solution with $0.05 \mathrm{M}$ sodium azide was measured using an RF1501 Shimadzu fluorometer in the emission range of 300 to $450 \mathrm{~nm}$ with excitation at $275 \mathrm{~nm}$. Five aqueous pyrene standards with concentrations ranging from 0.5 to $2.0 \mu \mathrm{g} \mathrm{L}^{-1}$ were used to produce a calibration curve $\left(R^{2}=0.99\right)$. Duplicates of a $1.5 \mathrm{~cm}$ diameter punch were added to the pyrene spiked MilliQ water and placed on a shaker table in a closed $50 \mathrm{~mL}$ amber vial to equilibrate for 30 days at ambient conditions (Flores-Cervantes et al., 2009). The final fluorescence was measured and used to calculate the $\mathrm{BC}$ concentration $\left(\mathrm{BC}_{\mathrm{PFL}}\right)$ as outlined by Flores-Cervantes et al. (2009). The methodological detection limit was $0.1 \mu \mathrm{g} \mathrm{cm}{ }^{-2}$ of $\mathrm{BC}_{\mathrm{PFL}}$ (methodological information in the Supplement).

\subsection{Optical transmission attenuation (OT-21)}

Filter samples were analyzed for $\mathrm{BC}\left(\mathrm{BC}_{\text {OT21 }}\right)$ at Magee Scientific in Berkeley, California, using the optical Transmissometer Model OT21. This instrument measured the light attenuation through a $25 \mathrm{~mm}$ diameter punch of each QFF at the a wavelength of $880 \mathrm{~nm}$, and compared it to that of a blank filter using an absorption coefficient of $16.6 \mathrm{~m}^{2} \mathrm{~g}^{-1}$ to convert the absorbance to a $\mathrm{BC}_{\mathrm{OT} 21}$ concentration (Husain et al., 2007; Ahmed et al., 2009; Dutkiewicz et al., 2009); furthermore, the detection limit was $\pm 0.06 \mu \mathrm{g} \mathrm{cm}^{-2}$.

\subsection{Methodological comparisons}

We applied multiple methods to quantify EC and BC concentrations to gain insights into the forms (charcoal, soot), long range transport capability, and recalcitrance of combustionderived aerosols in a remote environment. The CTO-375 method has been shown to detect only the most reduced and condensed EC forms since the thermal oxidization process will remove the less thermally stable forms of BC, such as charcoal (Flores-Cervantes et al., 2009). Thus, the measured $\mathrm{EC}_{\text {Сто }}$ has been termed in the literature soot-like carbon since it detects only the most refractory and structurally ordered portion of the $\mathrm{BC}$ combustion continuum (Gustafsson et al., 1997; Masiello 2004; Lohmann et al., 2009; Han et al., 2013).

Similarly, the TOT method also uses high-temperature treatments to quantify the fraction of EC present in aerosols. The TOT method was originally developed, in part, to detect diesel exhaust particles, which are generally more graphitized than biomass burning carbonaceous byproducts due to the lower oxygen to fuel ratio (Birch and Cary, 1996; Schmidt and Noack, 2000; Elmquist et al., 2006; Keiluweit et al., 2010). It is projected that the CTO-375 and TOT methods will give insight into the more reduced, thermally stable, and environmentally persistent forms of soot-like EC produced by the condensation of volatiles during combustion (Hammes et al., 2007). Typically, the CTO-375 quantifies a lower EC concentration compared to the TOT method on the same sample since it represents only the soot fraction of EC (Han et al., 2013).

The CTO-375 and TOT methods, in addition to quantifying the more thermally stable and lower volatile EC fraction of the combustion continuum, also measure the concentration of organic carbon. Thus, implementing these two thermally based detection methods allows for an additional intermethod comparison of the presence of the thermally unstable primary and secondary organic aerosols. Additionally, the CTO-375 method allows for the measurement of the stable carbon isotope ratio, allowing for source apportionment between the organic carbon and EC fractions.

The novel pyrene fluorescence loss technique does not have a thermal bias and is suggested to detect a broader portion of the $\mathrm{BC}$ combustion continuum, including charcoallike fractions. This pyrene fluorescence loss method has been shown to report black carbon in grass and wood chars while the CTO-375 method routinely oxidizes the entire sample (Flores-Cervantes et al., 2009). The PFL method utilizes the chemical adsorption of pyrene to black carbon particles and has been demonstrated to quantify the solid residue 
combustions byproducts (i.e., charcoal) in addition to condensed volatiles (i.e., soot). Likewise, the OT-21 method uses an optical approach and the wavelength of $880 \mathrm{~nm}$ has been shown to quantify larger fractions of forest fire-produced aerosols in comparison to the TOT method (Jeong et al., 2004).

We propose that the PFL and OT-21 methods will detect a broader spectrum of combustion-derived byproducts, whereas the CTO-375 and TOT methods are optimized to quantify only the soot and non-volatile fractions. Differences between quantified EC (CTO-375 and TOT) and BC (PFL and OT-21) values for the same sample would suggest the presence of non-soot-like carbon. Alternatively, similar values between these four methods would suggest that soot-like carbon dominated in the samples.

\subsection{Quality control and quality assurance}

Quality control and quality assurance was assessed on all QFF samples using a combination of blanks and standard reference materials. Field and laboratory blank QFFs were treated and handled identically to all samples. No carbon was detected on blank QFFs for the pyrene fluorescence loss method. We note that optical transmission attenuation corrects for the blank as part of the protocol. Carbon was detected on blank filters for the CTO-375 and TOT techniques. There was no difference found between the field and laboratory blanks. We subtracted the average blank BC concentration of $1.7 \pm 0.5 \mu \mathrm{g} \mathrm{cm}^{-2}$ for the CTO-375 method and $0.04 \pm 0.1 \mu \mathrm{g} \mathrm{cm}^{-2}$ for the TOT method from each sample. We hypothesized that this inherent carbon was entrained inside of the filters, and was liberated during the hightemperate oxidation step. We confirmed in follow-up experiments that the blank associated carbon remained constant regardless of the air volume filtered. A laboratory GFF blank was also quantified via pyrene fluorescence loss and CTO375. No $\mathrm{BC}_{\mathrm{PFL}}$ was detected and and a blank $\mathrm{EC}_{\mathrm{CTO}}$ value of $2.6 \pm 0.4 \mu \mathrm{g} \mathrm{cm}^{-2}$ was detected. We note that samples 1 and 22-24 could have had a higher associated blank carbon value if they were GFF instead of QFF filters.

Methodological quality control was assessed using the NIST standard reference material NIST 1649a (urban dust). The international standard grass char was also used for the CTO-375 method only as suggested by the BC ring trial (Hammes et al., 2007). Elemental carbon mass fractions for the CTO-375 method were within the expected range for NIST 1649a at $2.7 \pm 0.1 \%$. An insufficient mass of the grass char was recovered, as expected, since the CTO-375 is optimized to measure the soot-like fraction and chars are oxidized (Gustafsson et al., 1997; Flores-Cervantes et al., 2009). The absence of grass char recovery suggests that methodological charring did not occur. Higher $\mathrm{BC}_{\mathrm{PFL}}$ concentrations were detected with NIST 1649a (7.9\%) using the pyrene florescence loss method and the TOT method produced a median $\mathrm{EC}_{\mathrm{TOT}}$ value of $4.2 \pm 0.4 \%$, both as expected (Currie et al., 2002; Flores-Cervantes et al., 2009). The TOT method produced an expected median value of $4.2 \pm 0.4 \%$ (Currie et al., 2002). Precombusted sand blanks were also used for the CTO-375 and pyrene fluorescence loss methods with no carbon detected. Statistical analyses were conducted using the data analysis tool in Microsoft EXCEL.

\section{Results and discussion}

\subsection{Regional trends for black carbon with respect to the total organic carbon}

\subsubsection{General black carbon concentrations and trends}

The highest BC concentrations were found in the Caribbean Sea and the African plume (Table 3; Fig. 1). Concentrations of BC for the Caribbean Sea ranged from below instrumental detection limit (of all quantification methods) to $3.4 \mathrm{~g} \mathrm{~m}^{-3}$ and had an average regional concentration of $0.6 \pm 0.4 \mu \mathrm{g} \mathrm{m}^{-3}$. Black carbon concentrations for the African plume, located in the remote equatorial Atlantic, had an equivalent average concentration of $0.6 \pm 0.4 \mu \mathrm{g} \mathrm{m}^{-3}$ with concentrations ranging from below detection limit to $1.4 \mu \mathrm{g} \mathrm{m}^{-3}$. We had anticipated the greatest concentrations in the region to be impacted by the African plume; however, we had not expected the Caribbean Sea to have the overall highest measured BC concentrations. Samples collected from the Caribbean Sea were closest to land, suggesting that local urban/agricultural burning could have dominated the regional tropical marine boundary layer (Duncan et al., 2003). The samples collected in the African plume were between 815 and $1700 \mathrm{~km}$ directly removed from land, and at least $4300 \mathrm{~km}$ away from the projected source region of the African Savanna according to the backward wind trajectories.

Black carbon concentrations were lowest in the subtropical Atlantic (above the oligotrophic Sargasso Sea) and South America (>200 km removed from land in the tropical western Atlantic). Both regions had an average BC concentration of $0.2 \mu \mathrm{g} \mathrm{m}^{-3}$. Black carbon concentrations from the subtropical Atlantic and South American ranged from below detection limit to $0.6 \mu \mathrm{g} \mathrm{m}^{-3}$ and from 0.1 to $0.5 \mu \mathrm{g} \mathrm{m}^{-3}$, respectively. Backward wind trajectories suggest that the regional subtropical Atlantic air could have been diluted by clean Arctic air inputs, supporting the low BC concentrations we detected (Koch and Hansen, 2005; Wang et al., 2013; Fig. 1). The greatest measured $\mathrm{BC}$ concentration between these two regions was detected on the last sample, which was influenced by outflow from the North American airshed.

\subsubsection{Total organic carbon concentrations and trends}

Total organic carbon (TOC) concentrations varied considerably and followed a similar regional pattern as the $\mathrm{BC}$ (Table 2; Fig. 1). Total organic carbon concentrations were 
Table 2. Average regional total organic carbon concentrations and ranges $\left(\mu \mathrm{g} \mathrm{m}^{-3}\right)$ for the TOT methods $\left(\mathrm{TOC}^{\mathrm{a}}\right)$ and $\mathrm{CTO}^{-375}\left(\mathrm{TOC}^{\mathrm{b}}\right)$ methods and the $\delta^{13} \mathrm{C}$ value (\%o) for the total organic carbon and black carbon determined by the CTO-375 method.

\begin{tabular}{lrrrr}
\hline Regional average (range) & TOC $^{\mathbf{a}}$ & TOC $^{\mathbf{b}}$ & $\delta^{\mathbf{1 3}}$ C-TOC & $\delta^{\mathbf{1 3} \text { C-BC }}$ \\
\hline \multirow{2}{*}{ African plume } & $1.1 \pm 0.4$ & $0.9 \pm 0.5$ & $-21 \pm 4$ & $-17 \pm 5$ \\
& $(0.2-1.9)$ & $(0.1-1.5)$ & $(-19$ to -26$)$ & $(-2$ to -26$)$ \\
\hline \multirow{2}{*}{ Caribbean Sea } & $1.9 \pm 0.3$ & $1.8 \pm 1.7$ & $-22 \pm 8$ & $-34 \pm 18$ \\
& $(0.4-6.1)$ & $(0.4-5.8)$ & $(-9$ to -34$)$ & $(-22$ to -42$)$ \\
\hline \multirow{2}{*}{ South America } & $0.5 \pm 0.1$ & $0.4 \pm 0.1$ & $-27 \pm 2$ & $-28 \pm 14$ \\
& $(0.2-0.9)$ & $(0.2-0.5)$ & $(-24$ to -32$)$ & $(-16$ to -35$)$ \\
\hline \multirow{2}{*}{ Subtropical Atlantic } & $0.3 \pm 0.1$ & $0.2 \pm 0.0$ & $-23 \pm 5$ & $-15 \pm 12$ \\
& $(0.1-0.4)$ & $(0.2-0.3)$ & $(-17$ to -25$)$ & $(3$ to -27$)$ \\
\hline
\end{tabular}

Table 3. Average black carbon concentrations and range by region $\left(\mu \mathrm{g} \mathrm{m}^{-3}\right)$ using four different methods: the chemothermal oxidation at $375^{\circ} \mathrm{C}$ (CTO-375), thermal optical transmittance (TOT), pyrene fluorescence loss (PFL), and optical attenuation (OT-21).

\begin{tabular}{lrrrr}
\hline Regional average (range) & CTO-375 & TOT & PFL & OT-21 \\
\hline \multirow{2}{*}{ African plume } & $0.1 \pm 0.1$ & $0.8 \pm 0.4$ & $0.5 \pm 0.3$ & $0.8 \pm 0.4$ \\
& $(0-0.2)$ & $(0.2-1.4)$ & $(0.3-0.9)$ & $(0.2-1.3)$ \\
\hline \multirow{2}{*}{ Caribbean Sea } & $0.8 \pm 0.9$ & $0.3 \pm 0.2$ & $1.1 \pm 1.2$ & $0.2 \pm 0.2$ \\
& $(0-3.2)$ & $(0-0.6)$ & $(0-3.4)$ & $(0-0.7)$ \\
\hline \multirow{2}{*}{ South America } & $0.2 \pm 0.1$ & $0.2 \pm 0.1$ & $0.3 \pm 0.1$ & $0.3 \pm 0.2$ \\
& $(0.1-0.3)$ & $(0.1-0.2)$ & $(0.2-0.3)$ & $(0.1-0.5)$ \\
\hline \multirow{2}{*}{ Subtropical Atlantic } & $0.1 \pm 0.1$ & $0.2 \pm 0.0$ & $0.4 \pm 0.2$ & $0.2 \pm 0.1$ \\
& $(0-0.2)$ & $(0.2)$ & $(0.1-0.6)$ & $(0-0.3)$ \\
\hline
\end{tabular}

measured using two different instruments, an isotope ratio mass spectrometer and a Sunset TOT analyzer. Total organic carbon concentrations between the two methods were significantly correlated in the African plume and Caribbean Sea regions $\left(p\right.$ value $=0.002 ; R^{2}=0.98 ; p$ value $=3 \mathrm{E}^{-5}$; $R^{2}=0.84$, respectively). Greatest TOC concentrations, for both methods, were measured in the Caribbean Sea with a range from 0.3 to $6.1 \mu \mathrm{g} \mathrm{m}^{-3}$ and a regional average of $1.9 \pm 1.8 \mu \mathrm{g} \mathrm{m}^{-3}$. Our TOC concentrations exceeded the GISS ModelE simulations of $\leq 5.0 \mu \mathrm{g} \mathrm{m}^{-3}$, possibly due to a wildfire event which caused temporary elevated BC concentrations, and may not be representative of a seasonal summer TOC mean (Koch et al., 2007). The elevated TOC concentrations from the Caribbean Sea also could have included biomass generated molecules such as a macromolecular humic acids and polycyclic aromatic hydrocarbons.

Total organic carbon concentrations in the African plume also had a similar pattern to the $\mathrm{BC}$ and contained the second highest TOC concentration range of 0.1 to $1.9 \mu^{-3} \mathrm{~m}^{-3}$, with a regional average of $1.0 \pm 0.6 \mu \mathrm{g} \mathrm{m}^{-3}$. This agreed with the modeled organic carbon concentrations of 0.5 to $5.0 \mu \mathrm{g} \mathrm{m}^{-3}$ (Liousse et al., 1996; Koch et al. 2007). Likewise, previous field measurements across the Atlantic Ocean in the JulyAugust of 2002 and 2004 measured an average TOC aerosol concentration of $4.5 \pm 1.6 \mu \mathrm{m} \mathrm{m}^{-3}$ and $1.4 \pm 0.7 \mu \mathrm{m} \mathrm{m}^{-3}$, respectively (Bates et al., 2006). The TOC concentrations were greatest closer to the grassland burning source region. We propose that TOC concentrations in the marine boundary layer were a mix between degraded secondary organic aerosols from marine precursor volatile organic carbons, and primary organic aerosols ejected from sea spray (Keene et al., 2007; O'Dowd and Leeuw, 2007; Hodzic et al., 2010).

The lowest TOC concentrations, similar to the regional BC patterns, occurred in the South Atlantic (0.2 to 0.9 with a mean of $\left.0.4 \pm 0.2 \mu \mathrm{g} \mathrm{m}^{-3}\right)$ and the subtropical Atlantic $(0.1$ to 0.4 with a mean of $0.3 \pm 0.1 \mu \mathrm{g} \mathrm{m}^{-3}$ ) regions for both methods. The main form of TOC in these remote environments was likely marine secondary organic aerosols, thus may represent a background level of TOC for the remote marine boundary layer with minimal urban influence (O'Dowd and Leeuw, 2007). Model simulations in South America have estimated a wide range in organic matter concentrations from 0.1 to $1.0 \mu \mathrm{g} \mathrm{m}^{-3}$ (Koch et al., 2007). The same study had predicted low anthropogenic sulfate $(<100 \mathrm{pptv})$ which indicates that biomass burning rather than fossil fuel combustion is the primary mechanism for combustion-derived aerosols in this region. 


\subsection{3 $\mathrm{BC} / \mathrm{TOC}$ regional patterns}

The Caribbean Sea and South Atlantic both had the largest ratio of $\mathrm{EC}_{\mathrm{CTO}} / \mathrm{TOC}_{\mathrm{CTO}}(0.45)$. This ratio measured the fraction of soot-like $\mathrm{EC}\left(\mathrm{EC}_{\mathrm{CTO}}\right)$ that composed the organic aerosols (primary and secondary), thus implied that nearly $50 \%$ of the carbonaceous aerosols were soot like. The subtropical Atlantic region had an $\mathrm{EC}_{\mathrm{CTO}} / \mathrm{TOC}_{\mathrm{CTO}}$ of 0.36 , which also suggests that $\mathrm{EC}_{\mathrm{CTO}}$ composed large fractions of remote aerosols despite being removed from point sources of biomass burning and fossil fuel combustion. The African plume has the lowest regional $\mathrm{EC}_{\mathrm{CTO}} / \mathrm{TOC}_{\mathrm{CTO}}$ of 0.16 , which indicated that the organic aerosols within this plume dominate over the $\mathrm{EC}_{\mathrm{CTO}}$ transport.

The ratio of $\mathrm{EC}_{\mathrm{TOT}} / \mathrm{TOC}_{\mathrm{TOT}}$ was not significantly correlated to the $\mathrm{EC}_{\mathrm{CTO}} / \mathrm{TOC}_{\mathrm{CTO}}$ in any of the regions investigated during this study, but were opposite in trends. The highest $\mathrm{EC}_{\mathrm{TOT}} / \mathrm{TOC}_{\mathrm{TOT}}$ occurred in the African plume and the subtropical Atlantic at 0.73 and 0.67, respectively (Table 2). The lowest $\mathrm{EC}_{\mathrm{TOT}} / \mathrm{TOC}_{\mathrm{TOT}}$ was 0.40 for South America and 0.16 for the Caribbean Sea. The elevated BC concentrations in the Caribbean Sea, and to a lesser extent South America, suggest local burning activities had significant inputs of carbonaceous aerosols and were favored over longrange transport. Methodological comparisons of $\mathrm{EC}_{\mathrm{TOT}}$ and

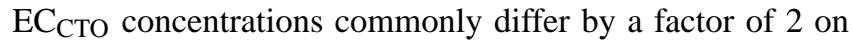
the same sample, implying different aerosol properties (Watson et al., 2005).

The difference in EC/ TOC ratios between the two methods (CTO-375 and TOT) reflects on black carbon properties and local vs. distant sources. We detected a fraction of EC by the TOT method which was oxidized as thermally unstable organic carbon in the CTO-375 method (Fig. 1). Thus, the tropical Atlantic atmosphere contained EC-like aerosols other than the extremely inert graphitic-like carbon which could contain valuable nutrients like nitrate and phosphate for the oligotrophic Atlantic (Talbot et al., 1986).

We used the $\mathrm{EC}_{\mathrm{CTO}}$ value, and its associated $\mathrm{TOC}_{\mathrm{CTO}}$ value, with the $\mathrm{BC}_{\mathrm{PFL}}$ concentration to assess the fraction of soot and charcoal-like aerosols in the study area, where $\mathrm{EC}_{\mathrm{CTO}}$ represents only soot-like carbon, $\mathrm{BC}_{\mathrm{PFL}}$ measures all portions of the $\mathrm{BC}$ combustion continuum, and $\mathrm{TOC}_{\mathrm{CTO}}$ measures the thermally unstable (non-black carbon) organic carbon (Fig. 1). We assumed that $\mathrm{BC}_{\mathrm{PFL}}$ would measure soot-like combustion byproducts in addition to the more thermally unstable fraction such as charcoal. Thus, we determined the fraction of $\mathrm{EC}_{\mathrm{CTO}}$, or soot-like carbon that composes the $\mathrm{BC}_{\mathrm{PFL}}$ in order to access soot-like vs. charcoal-like aerosols in this study region.

The average ratio of soot-like $\mathrm{EC}_{\mathrm{CTO}} / \mathrm{BC}_{\mathrm{PFL}}$ was $<1$ for all regions except for the Caribbean Sea (Fig. 1). The ratio of $\mathrm{EC}_{\mathrm{CTO}} / \mathrm{BC}_{\mathrm{PFL}}$ for the NIST standard reference material 1650 (diesel particulate matter) is 3.1, which indicates that our samples, with the possible exception to the Caribbean, were not dominated by fossil fuel-generated BC but by biomass-produced $\mathrm{BC}$ components, which is in agreement with previous studies (Andreae 1983; Swap et al. 1996). We suggest that the Caribbean Sea region was dominated by soot-like EC. The Caribbean Sea had a $\mathrm{EC}_{\mathrm{CTO}} / \mathrm{BC}_{\mathrm{PFL}}$ ratio of 1.2 , implying that $100 \%$ of the combustion-derived aerosols were soot-like and that minimal charcoal-like particulates were present.

The South American region contained the second highest ratio of $\mathrm{EC}_{\mathrm{CTO}} / \mathrm{BC}_{\mathrm{PFL}}$ at 0.6 (Fig. 1). The marine boundary layer of South America could be composed of $27 \%$ soot-like and $18 \%$ charcoal-like materials compared to the TOC $_{\text {Сто }}$. The African plume and subtropical Atlantic were dominated by the thermally unstable organic carbon that is a combination of secondary and primary organic aerosols. The African plume was calculated to be $87 \%$ thermally unstable organic carbon, $4 \%$ soot like, and $9 \%$ charcoal-like carbon. The African plume, although $>815 \mathrm{~km}$ from land, contained more charcoal-like particulates than soot like. Similarly, the remote and oligotrophic subtropical Atlantic region was estimated to be $64 \%$ thermally unstable organic carbon, $7 \%$ soot like, and $29 \%$ charcoal like. Both the African plume and subtropical Atlantic results reject our hypothesis that soot-like EC would be the dominant form of combustion-derived aerosols (Masiello 2004; Lohmann et al. 2009). This implies that charcoal like (and other combustionderived macromolecules) could be present in significant concentrations in remote marine locations.

\subsection{Stable carbon isotope analysis for source apportionment}

Stable carbon isotopes $\left(\delta^{13} \mathrm{C}\right)$ can be utilized to assess the source of both the $\mathrm{TOC}_{\mathrm{CTO}}$ and $\mathrm{EC}_{\mathrm{CTO}}$ carbon pools $(\mathrm{Ta}-$ ble 2). The $\delta^{13} \mathrm{C}$-TOC ${ }_{\mathrm{CTO}}$ values within the African plume $(-21 \%)$, Caribbean Sea $(-22 \%$ ), and subtropical Atlantic $(-23 \%)$ were indicative of a marine plankton signature. This marine plankton signature is likely a mix of degraded secondary organic aerosols and primary organic particulates from sea spray (Keene et al. 2007; O'Dowd and Leeuw 2007; Hodzic et al. 2010). A previous study found that primary submicron organic carbon aerosols can be present in significant concentrations in the mixed boundary layer, even in an oligotrophic environment (Keene et al., 2007). We cannot ignore that the $\delta^{13} \mathrm{C}-\mathrm{TOC}_{\mathrm{CTO}}$ range of -23 to $-21 \%$ o could also be a mixing of $\mathrm{C}_{4}$ and $\mathrm{C}_{3}$ carbon fixation constituents. However, previous studies have shown that the mixed boundary layer aerosols are dominated by marine organic carbon, thus marine plankton is the most probable source of TOC in these regions (Putaud et al., 2000; O'Dowd et al., 2004).

The South America regional $\delta^{13} \mathrm{C}-\mathrm{TOC}_{\mathrm{CTO}}$ was more depleted at $-27 \%$, which is indicative of $\mathrm{C}_{3}$ plant material and is too depleted to be solely marine plankton or $\mathrm{C}_{4}$ grass material (Table 2). The backward wind trajectories showed that the air originated from a distal source in southern Africa, but local burning activities of $\mathrm{C}_{3}$ plants and crops in the Amazon 
rain forest was likely a significant source of the organic material.

Both the African plume and subtropical Atlantic regions had $\delta^{13} \mathrm{C}-\mathrm{EC}_{\mathrm{CTO}}$ values more enriched than their $\delta^{13} \mathrm{C}$ -

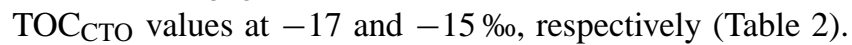
This enrichment strongly indicates that the $\mathrm{EC}_{\text {СТО was a }}$ byproduct of grass combustion, presumably from the African Savanna based on backward wind trajectories (Fig. 1; Farquhar et al., 1989; Lohmann et al., 2009). Underlying sediments in the African plume region, such as from the Niger Delta, have been measured to be similarly enriched at $-17 \%$, which agrees with our data (Holtvoeth et al., 2005).

The average $\delta^{13} \mathrm{C}-\mathrm{EC}_{\mathrm{CTO}}$ values of the Caribbean Sea $(-34 \% o)$ and South America $(-28 \%$ ) were strongly depleted, which is indicative of $\mathrm{C}_{3}$ carbon fixation carbon. We retrieved the intensity of open forest fires during the sampling time from the global fire emissions database (Giglio et al., 2003; Davies et al., 2004). Elevated concentrations of $\mathrm{EC}_{\mathrm{CTO}}$ could be partly due to forest fires, specifically in Cuba and central South America. We reasoned that $\mathrm{C}_{4}$ grass combustion was not an important source of $\mathrm{EC}_{\mathrm{CTO}}$ to the Caribbean Sea and South America regions, thus more local burning events were a likely source of the combustionderived aerosols.

\subsection{Carbonaceous combustion aerosol analysis by sub-region}

\subsubsection{African plume}

A primary objective of this study was to sample the African emission plume to determine if the remote tropical Atlantic could be receiving significant inputs of combustion-derived aerosols. The GISS ModelE aerosol simulation estimated that up to $60 \%$, and an average of $18 \%$, of the global $\mathrm{BC}$ from biomass emissions originates from Africa, most of which are transported to the Atlantic Ocean (Koch et al. 2007). We sampled this plume during the southern hemispheric dry season when large-scale South African Savanna fires were frequent (Cahoon et al., 1992). Approximately $13 \%$ of the air parcels originated from the African continent according to the mean backward wind trajectory predictions (Fig. 1).

African plume $\mathrm{EC}_{\mathrm{CTO}}$ concentrations resulted in distinctly different concentrations compared to the other three methods. The $\mathrm{EC}_{\mathrm{CTO}}\left(0.1 \mu \mathrm{g} \mathrm{m}^{-3}\right)$ detected the lowest concentrations and $\mathrm{EC}_{\text {TOT }}$ and $\mathrm{BC}_{\text {OT21 }}$ detected the greatest concentrations, both with regional averages of $0.8 \mu \mathrm{g} \mathrm{m}^{-3}$ (Table 3). Model simulations from the GISS ModelE estimated that $\mathrm{BC}$ concentrations in this region could range from 0.5 to $1.0 \mu \mathrm{g} \mathrm{m}^{-3}$, with $\mathrm{BC}$ concentrations decreasing with increasing distance from Africa (Koch et al., 2007; Allen et al., 2012). Our data found a similar trend of decreasing BC concentrations with distance from the African Savanna, however, many of our concentrations exceeded this model simulation.
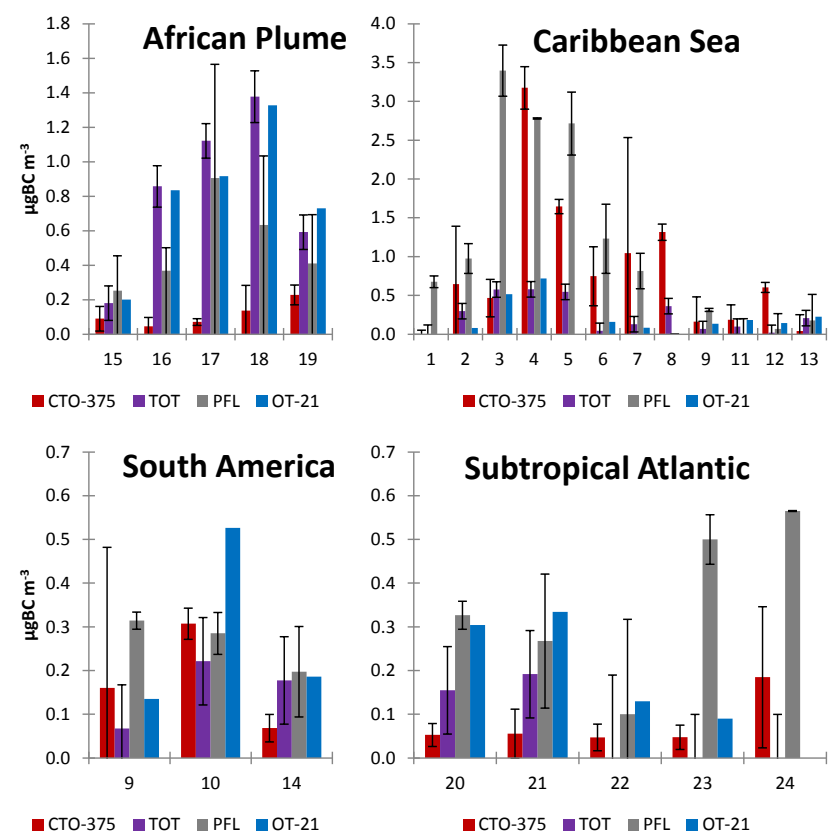

Figure 2. Comparison of black carbon concentrations $\left(\mu \mathrm{g} \mathrm{m}^{-3}\right)$ from the four selected methods grouped by region with one standard deviation. Error associated with the OT21 method was $\pm 0.1 \mu \mathrm{g} \mathrm{m}^{-3}$.

Aerosols from Africa during the Austral winter could compose a higher contribution to the global $\mathrm{BC}$ emissions than previously believed, which could cause changes in moisture transport and climate forcing, as well as the deposition of aerosols into the ocean.

The highest $\mathrm{EC}_{\mathrm{TOT}}$ concentration in the African plume region was $1.4 \mu \mathrm{g} \mathrm{m}^{-3}$, which was close in magnitude to the highest $\mathrm{BC}_{\mathrm{OT} 21}$ concentration $\left(1.3 \mu \mathrm{g} \mathrm{m}^{-3}\right)$ and $\mathrm{BC}_{\mathrm{PFL}}$ concentration $\left(0.9 \mu \mathrm{g} \mathrm{m}^{-3}\right)$. Both $\mathrm{BC}_{\mathrm{PFL}}$ and $\mathrm{BC}_{\mathrm{OT} 21}$ were found to be significantly correlated to each other $(p$ value $=0.01$; $\left.R^{2}=0.90\right)$. Additionally, the $\mathrm{EC}_{\mathrm{TOT}}$ and $\mathrm{EC}_{\mathrm{CTO}}$ were also significantly correlated ( $p$ value $=0.006 ; R^{2}=0.94$ ). The non-thermal methods yielded $\mathrm{BC}_{\mathrm{PFL}}$ and $\mathrm{BC}_{\mathrm{OT} 21}$ concentrations similar to model simulations and were elevated compared to the convention of $40 \mathrm{ng} \mathrm{m}^{-3}$ used to defined "clean" area over North America (Cavalli et al., 2004; O'Dowd et al., 2004). These concentrations are also elevated compared to the mixed boundary layer current over the oligotrophic southeast Pacific of which $2 \mathrm{ng} \mathrm{m}^{-3}$ was detected with single particle soot photometer instrumentation (Shank et al., 2012).

\subsubsection{Caribbean Sea}

The greatest concentrations of combustion-derived aerosols measured in this study occurred in the Caribbean Sea region, particularly between the highly developed and populated islands of the Dominican Republic and Puerto Rico (Table 3; Fig. 2). The greatest measured $\mathrm{BC}$ concentration 
$\left(\mathrm{BC}_{\mathrm{PFL}}\right)$ had a regional average of $1.1 \mu \mathrm{g} \mathrm{m}^{-3}$ with four of the samples exceeding $1 \mu \mathrm{g} \mathrm{m}^{-3}$. Similarly, EC $_{\mathrm{CTO}}$ had a maximum concentration of $3.2 \mu \mathrm{g} \mathrm{m}^{-3}$ and a regional average of $0.8 \mu \mathrm{g} \mathrm{m}^{-3}$. The $\mathrm{BC}_{\mathrm{PFL}}$ and $\mathrm{BC}_{\mathrm{OT} 21}$ were found to be significantly correlated ( $p$ value $=0.048 ; R^{2}=0.37$ ) as was the $\mathrm{BC}_{\mathrm{OT} 21}$ and $\mathrm{EC}_{\mathrm{TOT}}$ method ( $p$ value $=0.007$; $R^{2}=0.62$ ).

Few BC concentrations have been reported for the Caribbean Sea, leading to poor resolution in model predictions in the marine boundary layer. Mean summertime BC observation and model predictions in this region display concentrations ranging from $0.01-0.1 \mu \mathrm{g} \mathrm{m}^{-3}$ (Hansen et al., 1990; Koch et al. 2007; Wang et al., 2013). All measurements of EC and BC in this study exceed the previous model simulations and field investigations. We caution that model estimates are generally integrated over larger vertical and horizontal scales than the direct measurements from this study; hence model estimates may be diluted in comparison to our measurements. Our data cannot differentiate if these elevated $\mathrm{BC}$ and $\mathrm{EC}$ concentrations are typical for the summer, or are a time specific anomaly, such as the occurrence of nearby wildfires.

\subsubsection{South America}

The South America region was represented by three samples collected $>200 \mathrm{~km}$ off the Brazilian Coast. Black and elemental carbon concentrations were lower in the South American region than the Caribbean Sea (Table 3). These samples represented southern hemispheric air (austral winter), as indicated by the backward wind trajectories (Fig. 1). The wind directionality was away from the South American Continent, thus unfavorable for large organic aerosol deposition. Samples were taken in close proximity to the Amazon River mouth.

The highest regionally averaged concentration was $0.3 \mu \mathrm{g} \mathrm{m}^{-3}$ for both $\mathrm{BC}_{\mathrm{PFL}}$ and $\mathrm{BC}_{\mathrm{OT} 21}$. Elemental carbon $\left(\mathrm{EC}_{\mathrm{CTO}}\right.$ and $\mathrm{EC}_{\mathrm{TOT}}$ ) had an average concentration of $0.2 \mu \mathrm{g} \mathrm{m}^{-3}$. Black carbon concentrations are generally higher in the winter months due to increased biomass burning and dryness, which reduces wet deposition (Wolff and Cachier, 1998; Sharma et al., 2004; Novakov and Rosen, 2013). The atmospheric residence time for soot-like BC in the Southern Hemisphere is longer, averaging $\sim 8$ days (Chuang et al., 2002; Reddy and Boucher 2007), suggesting that we sampled local aerosols from Brazil as well as long range transport aerosols from southern Africa.

Very few BC and EC measurements have been made in the remote South American region, especially in the marine boundary layer. The South America region had been estimated to range in $\mathrm{BC}$ aerosols from $0.02-0.5 \mu \mathrm{g} \mathrm{m}^{-3}$ with concentrations highest closest to the Amazon River mouth and diminishing with distance offshore (Koch et al. 2005; Koch et al. 2007). Our measurements of 0.2 to $0.3 \mu \mathrm{g} \mathrm{m}^{-3}$ fall within this expected range and agree with the Fire Emis- sion Database that we sampled above regional BC averages, but not at peak concentrations (Cooke and Wilson, 1996; Koch and Hansen, 2005). The measured concentrations reported here suggest that atmospheric deposition is an important transport mechanism of $\mathrm{BC}$ to the tropical Atlantic Ocean, in addition to fluvial deposition from the Amazon River.

\subsubsection{Subtropical Atlantic}

Northern hemispheric air originating from the open ocean and the Arctic was sampled in the subtropical Atlantic region which crossed the Sargasso Sea (Fig. 1). Concentrations of $\mathrm{BC}$ and $\mathrm{EC}$ were low in the subtropical Atlantic, as expected, but increased upon approaching the United States coast. Previous studies have suggested that the clean Arctic air inputs would result in lowered $\mathrm{BC}$ concentrations, as compared to urban regions, with concentrations $\geq 0.05 \mu \mathrm{g} \mathrm{m}^{-3}$ (Koch and Hansen, 2005). Similarly, the GISS ModelE simulates than $\mathrm{BC}$ inputs would be diluted by the organic matter aerosols in this region, which is supported by our data (Koch et al. 2007).

Samples from the subtropical Atlantic displayed greatest $\mathrm{BC}$ concentrations near the African and United States coast and smallest across the subtropical gyre. Regional BC averages for this region were among the lowest measured in this study. Both $\mathrm{BC}_{\mathrm{PFL}}$ and $\mathrm{BC}_{\mathrm{OT} 21}$ measured their overall lowest mean concentrations in this region at $0.4 \mu \mathrm{g} \mathrm{m}^{-3}$ and $0.2 \mu \mathrm{g} \mathrm{m}^{-3}$, respectively. The $\mathrm{EC}_{\text {Сто concentration was an }}$ average of $0.1 \mu \mathrm{g} \mathrm{m}^{-3}$ for the subtropical Atlantic, which was comparable to the method's lowest regional average, measured in the African plume $\left(0.1 \mu \mathrm{g} \mathrm{m}^{-3}\right)$.

\section{Conclusions}

Black carbon particulates were collected in four sub-regions within the tropical Atlantic Ocean to determine the concentrations and distributions of combustion-derived aerosols in a remote and poorly sampled region. As expected, black carbon concentrations from $\mathrm{C}_{4}$ grass combustion were elevated in the African emission plume at 0.1 to $0.8 \mu \mathrm{g} \mathrm{m}^{-3}$. However, the greatest overall black carbon concentrations were measured in the Caribbean Sea at concentrations up to $1.1 \mu \mathrm{g} \mathrm{m}^{-3}$. Black carbon concentrations were still elevated above "clean air" concentrations of $40 \mathrm{ng} \mathrm{m}^{-3}$ in all subregions. Soot-like carbon was expected to be the dominant type of combustion-derived aerosols according to the black carbon combustion continuum. Multiple analytical methods were implemented to assess the contributions of thermally unstable organic carbon, soot-like carbon, and charcoal-like carbon in the tropical marine boundary layer. We determined that up to $29 \%$ of the subtropical Atlantic (over the oligotrophic Sargasso Sea), $19 \%$ of the western Atlantic (South America), and $9 \%$ of the African emission plume could be 
composed of charcoal-like aerosols. Future work should aim to both measure the entire black carbon combustion continuum and to apportion charcoal-like versus soot-like particulates when evaluating carbonaceous aerosols.

\section{The Supplement related to this article is available online at doi:10.5194/acp-14-7431-2014-supplement.}

Acknowledgements. We thank the National Science Foundation for support (OCE-0851044) and the crew and captain of the $\mathrm{R} / \mathrm{V}$ Endeavor for their help with collecting the samples. We acknowledge the help of A. D. A. Hansen (Magee Scientific), Denise Napolitano and Youliang Wang (Arizona State University), Rick McKinney and Julia Sullivan (U.S. Environmental Protection Agency), Torey Hart (URI) and Hilary Hamer (RPI).

Edited by: A. Petzold

\section{References}

Ahmed, T., Dutkiewicz, V. A., Shareef, A., Tuncel, G., Tuncel, S., and Husain, L.: Measurement of black carbon (BC) by an optical method and a thermal-optical method: intercomparison for four sites, Atmos. Environ., 43, 6305-6311, doi:10.1016/j.atmosenv.2009.09.031, 2009.

Allen, R. J., Sherwood, S. C., Norris, J. R., and Zender, C. S.: Recent Northern Hemisphere tropical expansion primarily driven by black carbon and tropospheric ozone, Nature, 485, 350-U393, doi:10.1038/Nature11097, 2012.

Andreae, M. O.: Soot carbon and excess fine potassium - longrange transport of combustion-derived aerosols, Science, 220, 1148-1151, doi:10.1126/science.220.4602.1148, 1983.

Andreae, M. O. and Gelencsér, A.: Black carbon or brown carbon? The nature of light-absorbing carbonaceous aerosols, Atmos. Chem. Phys., 6, 3131-3148, doi:10.5194/acp-6-3131-2006, 2006.

Bates, T. S., Anderson, T. L., Baynard, T., Bond, T., Boucher, O., Carmichael, G., Clarke, A., Erlick, C., Guo, H., Horowitz, L., Howell, S., Kulkarni, S., Maring, H., McComiskey, A., Middlebrook, A., Noone, K., O’Dowd, C. D., Ogren, J., Penner, J., Quinn, P. K., Ravishankara, A. R., Savoie, D. L., Schwartz, S. E., Shinozuka, Y., Tang, Y., Weber, R. J., and Wu, Y.: Aerosol direct radiative effects over the northwest Atlantic, northwest Pacific, and North Indian Oceans: estimates based on in-situ chemical and optical measurements and chemical transport modeling, Atmos. Chem. Phys., 6, 1657-1732, doi:10.5194/acp-6-1657-2006, 2006.

Birch, M. E. and Cary, R. A.: Elemental carbon-based method for monitoring occupational exposures to particulate diesel exhaust, Aerosol. Sci. Tech., 25, 221-241, doi:10.1080/02786829608965393, 1996.

Bond, T. C., Streets, D. G., Yarber, K. F., Nelson, S. M., Woo, J. H., and Klimont, Z.: A technology-based global inventory of black and organic carbon emissions from combustion, J. Geophys. Res.-Atmos., 109, D14203, doi:10.1029/2003jd003697, 2004.

Bond, T. C., Doherty, S. J., Fahey, D. W., Forster, P. M., Berntsen, T., DeAngelo, B. J., Flanner, M. G., Ghan, S., Kärcher, B., Koch, D., Kinne, S., Kondo, Y., Quinn, P. K., Sarofirm, M. C., Schultz, M. G., Schulz, M., Venkataraman, C., Zhang, H., Zhang, S., Bellouin, N., Guttikunda, S. K., Hopke, P. K., Jacobson, M. Z., Kaiser, J. W., Klimont, Z., Lohmann, U., Schwarz, J. P., Shindell, D., Storelvmo, T., Warren, S. G., and Zender, C. S.: Bounding the role of black carbon in the climate system: A scientific assessment, J. Geophys. Res.Atmos., 118, 5380-5552, doi:10.1002/jgrd.50171, 2013.

Cahoon, D. R., Stocks, B. J., Levine, J. S., Cofer, W. R., and Oneill, K. P.: Seasonal distribution of African savanna fires, Nature, 359, 812-815, doi:10.1038/359812a0, 1992.

Cavalli, F., Facchini, M. C.; Decesari, S., Mircea, M., Emblico, L., Fuzzi, S., Ceburnis, D., Yoon, Y. J., O’Dowd, C. D., Putaud, J. P., and Dell'Acqua, A.: Advances in characterization of size-resolved organic matter in marine aerosol over the North Atlantic, J. Geophys. Res.-Atmos., 109, doi:10.1029/2004jd005137, 2004.

Chester, R., Griffiths, A. G., and Hirst, J. M.: Influence of soilsized atmospheric particulates on the elemental L chemistry of the deep-sea sediments of the Northeastern Atlantic, Mar. Geol., 32, 141-154, doi:10.1016/0025-3227(79)90150-6, 1979.

Chow, J. C., Watson, J. G., Doraiswamy, P., Chen, L. W. A., Sodeman, D. A., Lowenthal, D. H., Park, K., Arnott, W. P., and Motallebi, N.: Aerosol light absorption, black carbon, and elemental carbon at the Fresno Supersite, California, Atmos. Res., 93, 874887, doi:10.1016/j.atmosres.2009.04.010, 2009.

Chuang, C. C., Penner, J. E., Prospero, J. M., Grant, K. E., Rau, G. H., and Kawamoto, K.: Cloud susceptibility and the first aerosol indirect forcing: sensitivity to black carbon and aerosol concentrations, J. Geophys. Res.-Atmos., 107, 4564, doi:10.1029/2000jd000215, 2002.

Cooke, W. F. and Wilson, J. J. N.: A global black carbon aerosol model, J. Geophys. Res.-Atmos., 101, 19395-19409, doi:10.1029/96jd00671, 1996.

Corrigan, C. E., Roberts, G. C., Ramana, M. V., Kim, D., and Ramanathan, V.: Capturing vertical profiles of aerosols and black carbon over the Indian Ocean using autonomous unmanned aerial vehicles, Atmos. Chem. Phys., 8, 737-747, doi:10.5194/acp-8-737-2008, 2008.

Currie, L. A., Benner, B. A., Kessler, J. D., Klinedinst, D. B., Klouda, G. A., Marolf, J. V., Slater, J. F., Wise, S. A., Cachier, H., Cary, R., Chow, J. C., Watson, J., Druffel, E. R. M., Masiello, C. A., Eglinton, T. I., Pearson, A., Reddy, C. M., Gustafsson, O., Quinn, J. G., Hartmann, P. C., Hedges, J. I., Prentice, K. M., Kirchstetter, T. W., Novakov, T., Puxbaum, H., and Schmid, H.: A critical evaluation of interlaboratory data on total, elemental, and isotopic carbon in the carbonaceous particle reference material, NIST SRM 1649a, J. Res. Natl. Inst. Stan., 107, 279-298, doi:10.6028/Jres.107.022, 2002.

Davies, D., Kumar, S., and Descloitres, J.: Global fire monitoring using MODIS near-real-time satelitte data, GIM International, 18, 41-43, 2004.

Draxler, R. R. and Rolph, G. D.: HYSPLIT (HYbrid Single-Particle Lagrangian Integrated Trajectory) Model access via NOAA ARL READY Website, available at: http://www.arl.noaa.gov/ 
HYSPLIT.php, NOAA Air Resources Laboratory, College Park, MD, 2013.

Duncan, B. N., Martin, R. V., Staudt, A. C., Yevich, R., and Logan, J. A.: Interannual and seasonal variability of biomass burning emissions constrained by satellite observations, J. Geophys. Res.-Atmos., 108, doi:10.1029/2002jd002378, 2003.

Dutkiewicz, V. A., Alvi, S., Ghauri, B. M., Choudhary, M. I., and Husain, L.: Black carbon aerosols in urban air in South Asia, Atmos. Environ., 43, 1737-1744, doi:10.1016/j.atmosenv.2008.12.043, 2009.

Elmquist, M., Cornelissen, G., Kukulska, Z., and Gustafsson, O.: Distinct oxidative stabilities of char versus soot black carbon: implications for quantification and environmental recalcitrance, Global Biogeochem. Cy., 20, Gb2009, doi:10.1029/2005gb002629, 2006.

Farquhar, G. D., Ehleringer, J. R., and Hubick, K. T.: Carbon Isotope Discrimination and Photosynthesis, Annu. Rev. Plant Physiol. Plant Molec. Biol., 40, 503-537, doi:10.1146/annurev.arplant.40.1.503, 1989.

Flores-Cervantes, D. X., Reddy, C. M., and Gschwend, P. M.: Inferring black carbon concentrations in particulate organic matter by observing pyrene fluorescence losses, Environ. Sci. Technol., 43, 4864-4870, doi:10.1021/Es900043c, 2009.

Forbes, M. S., Raison, R. J., and Skjemstad, J. O.: Formation, transformation and transport of black carbon (charcoal) in terrestrial and aquatic ecosystems, Sci. Total. Environ., 370, 190-206, doi:10.1016/j.scitotenv.2006.06.007, 2006.

Gelinas, Y., Prentice, K. M., Baldock, J. A., and Hedges, J. I.: An improved thermal oxidation method for the quantification of soot/graphitic black carbon in sediments and soils, Environ. Sci. Technol., 35, 3519-3525, doi:10.1021/Es010504c, 2001.

Giglio, L. D. J., Justice, C. O., and Kaufman, Y. J.: An enhanced cotextual fire detection algorithm for MODIS, Remote. Sens. Environ., 87, 273-282, 2003.

Goldberg, E. D.: Black Carbon in the Environment, Wiley, New York, New York, USA, 1985.

Gustafsson, O., Haghseta, F., Chan, C., MacFarlane, J., and Gschwend, P. M.: Quantification of the dilute sedimentary soot phase: implications for PAH speciation and bioavailability, Environ. Sci. Technol., 31, 203-209, doi:10.1021/Es960317s, 1997.

Gustafsson, O., Krusa, M., Zencak, Z., Sheesley, R. J., Granat, L., Engstrom, E., Praveen, P. S., Rao, P. S. P., Leck, C., and Rodhe, H.: Brown Clouds over South Asia: Biomass or Fossil Fuel Combustion? Science, 323, 495-498, doi:10.1126/science.1164857, 2009

Hammes, K., Schmidt, M. W. I., Smernik, R. J., Currie, L. A., Ball, W. P., Nguyen, T. H., Louchouarn, P., Houel, S., Gustafsson, O., Elmquist, M., Cornelissen, G., Skjemstad, J. O., Masiello, C. A., Song, J., Peng, P., Mitra, S., Dunn, J. C., Hatcher, P. G., Hockaday, W. C., Smith, D. M., HartkopfFroeder, C., Boehmer, A., Luer, B., Huebert, B. J., Amelung, W., Brodowski, S., Huang, L., Zhang, W., Gschwend, P. M., FloresCervantes, D. X., Largeau, C., Rouzaud, J. N., Rumpel, C., Guggenberger, G., Kaiser, K., Rodionov, A., Gonzalez-Vila, F. J., Gonzalez-Perez, J. A., de la Rosa, J. M., Manning, D. A. C., Lopez-Capel, E., and Ding, L.: Comparison of quantification methods to measure fire-derived (black/elemental) carbon in soils and sediments using reference materials from soil, wa- ter, sediment and the atmosphere, Global Biogeochem. Cy., 21, Gb3016, doi:10.1029/2006gb002914, 2007.

Han, Y. M., Chen, A., Cao, J. J., Fung, K., Ho, F., Yan, B. Z., Zhan, C. L. L., Liu, S. X., Wei, C., and An, Z. S.: Thermal/Optical Methods for Elemental Carbon Quantification in Soils and Urban Dusts: Equivalence of Different Analysis Protocols, PLOS One, 8, doi:10.1371/journal.pone.0083462, 2013.

Hansen, A. D. A., Artz, R. S., Pszenny, A. A. P., Larson, R. E.: Aerosol black carbon and radon as tracers for air mass origin over the North Atlantic Ocean, Global Biogeochem. Cy., 4, 189199, 1990.

Hodzic, A., Jimenez, J. L., Madronich, S., Canagaratna, M. R., DeCarlo, P. F., Kleinman, L., and Fast, J.: Modeling organic aerosols in a megacity: potential contribution of semi-volatile and intermediate volatility primary organic compounds to secondary organic aerosol formation, Atmos. Chem. Phys., 10, 5491-5514, doi:10.5194/acp-10-5491-2010, 2010.

Hoetzel, S., Dupont, L., Schefuss, E., Rommerskirchen, F., and Wefer, G.: The role of fire in Miocene to Pliocene C-4 grassland and ecosystem evolution, Nat. Geosci., 6, 1027-1030, doi:10.1038/Ngeo1984, 2013.

Holtvoeth, J., Kolonic, S., and Wagner, T.: Soil organic matter as an important contributor to late Quaternary sediments of the tropical West African continental margin, Geochim. Cosmochim. Ac., 69, 2031-2041, doi:10.1016/j.gca.2004.09.030, 2005.

Husain, L., Dutkiewicz, V. A., Khan, A., and Ghauri, B. M.: Characterization of carbonaceous aerosols in urban air, Atmos. Environ., 41, 6872-6883, doi:10.1016/j.atmosenv.2007.04.037, 2007.

Jeong, C. H., Hopke, P. K., Kim, E., and Lee, D. W.: The comparison between thermal- optical transmittance elemental carbon and Aethalometer black carbon measured at multiple monitoring sites, Atmos. Environ., 38, 5193-5204, doi:10.1016/j.atmosenv.2004.02.065, 2004.

Keene, W. C., Maring, H., Maben, J. R., Kieber, D. J., Pszenny, A. A. P., Dahl, E. E., Izaguirre, M. A., Davis, A. J., Long, M. S., Zhou, X. L., Smoydzin, L., and Sander, R.: Chemical and physical characteristics of nascent aerosols produced by bursting bubbles at a model air-sea interface, J. Geophys. Res.-Atmos., 112, doi:10.1029/2007jd008464, 2007.

Keiluweit, M., Nico, P. S., Johnson, M. G., and Kleber, M.: Complexity of aromatic carbon in biomass-derived black carbon (biochar): Implications for molecular structure and sorptive interactions, Abstracts of Papers of the American Chemical Society, 240, 2010.

Koch, D., Bond, T. C., Streets, D., Unger, N., and van der Werf, G. R.: Global impacts of aerosols from particular source regions and sectors, J. Geophys. Res.-Atmos., 112, doi:10.1029/2005jd007024, 2007.

Koch, D. and Hansen, J.: Distant origins of Arctic black carbon: a Goddard Institute for Space Studies ModelE experiment, J. Geophys. Res.-Atmos., 110, D04204, doi:10.1029/2004jd005296, 2005.

Koch, D., Schulz, M., Kinne, S., McNaughton, C., Spackman, J. R., Balkanski, Y., Bauer, S., Berntsen, T., Bond, T. C., Boucher, O., Chin, M., Clarke, A., De Luca, N., Dentener, F., Diehl, T., Dubovik, O., Easter, R., Fahey, D. W., Feichter, J., Fillmore, D., Freitag, S., Ghan, S., Ginoux, P., Gong, S., Horowitz, L., Iversen, T., Kirkevåg, A., Klimont, Z., Kondo, Y., Krol, M., Liu, X., Miller, R., Montanaro, V., Moteki, N., Myhre, G., 
Penner, J. E., Perlwitz, J., Pitari, G., Reddy, S., Sahu, L., Sakamoto, H., Schuster, G., Schwarz, J. P., Seland, Ø., Stier, P., Takegawa, N., Takemura, T., Textor, C., van Aardenne, J. A., and Zhao, Y.: Evaluation of black carbon estimations in global aerosol models, Atmos. Chem. Phys., 9, 9001-9026, doi:10.5194/acp-9-9001-2009, 2009.

Lavanchy, V. M. H., Gaggeler, H. W., Nyeki, S., and Baltensperger, U.: Elemental carbon (EC) and black carbon (BC) measurements with a thermal method and an aethalometer at the high-alpine research station Jungfraujoch, Atmos. Environ., 33, 2759-2769, doi:10.1016/S1352-2310(98)00328-8, 1999.

Liousse, C., Penner, J. E., Chuang, C., Walton, J. J., Eddleman, H., and Cachier, H.: A global three-dimensional model study of carbonaceous aerosols, J. Geophys. Res.-Atmos., 101, 1941119432, doi:10.1029/95jd03426, 1996.

Liu, X. H., Penner, J. E., and Wang, M. H.: Influence of anthropogenic sulfate and black carbon on upper tropospheric clouds in the NCAR CAM3 model coupled to the IMPACT global aerosol model, J. Geophys. Res.-Atmos., 114, doi:10.1029/2008jd010492, 2008.

Lohmann, R., Bollinger, K., Cantwell, M., Feichter, J., FischerBruns, I., and Zabel, M.: Fluxes of soot black carbon to South Atlantic sediments, Global Biogeochem. Cy., 23, Gb1015, doi:10.1029/2008gb003253, 2009.

Masiello, C. A.: New directions in black carbon organic geochemistry, Mar. Chem., 92, 201-213, doi:10.1016/j.marchem.2004.06.043, 2004.

Novakov, T. and Rosen, H.: The black carbon story: early history and new perspectives, Ambio, 42, 840-851, doi:10.1007/s13280013-0392-8, 2013.

O'Dowd, C. D. and De Leeuw, G.: Marine aerosol production: a review of the current knowledge, Phil. T. R. Soc. A., 365, 17531774, doi:10.1098/rsta.2007.2043, 2007.

O’Dowd, C. D., Facchini, M. C., Cavalli, F., Ceburnis, D., Mircea, M., Decesari, S., Fuzzi, S., Yoon, Y. J., and Putaud, J. P.: Biogenically driven organic contribution to marine aerosol, Nature, 431, 676-680, doi:10.1038/Nature02959, 2004.

Ogren, J. A. and Charlson, R. J.: Elemental Carbon in the Atmosphere - Cycle and Lifetime, Tellus B, 35, 241-254, doi:10.1111/j.1600-0889.1983.tb00027.x, 1983

Park, K., Chow, J. C., Watson, J. G., Trimble, D. L., Doraiswamy, P., Park, K., Arnott, W. P., Stroud, K. R., Bowers, K., Bode, R., Petzold, A., and Hansen, A. D. A.: Comparison of continuous and filter-based carbon measurements at the Fresno Supersite, J. Air Waste. Manage., 56, 474-491, 2006.

Perry, K. D., Cahill, T. A., Eldred, R. A., Dutcher, D. D., and Gill, T. E.: Long-range transport of North African dust to the eastern United States, J. Geophys. Res.-Atmos., 102, 1122511238, doi:10.1029/97jd00260, 1997.

Petzold, A., Ogren, J. A., Fiebig, M., Laj, P., Li, S.-M., Baltensperger, U., Holzer-Popp, T., Kinne, S., Pappalardo, G., Sugimoto, N., Wehrli, C., Wiedensohler, A., and Zhang, X.-Y.: Recommendations for reporting "black carbon" measurements, Atmos. Chem. Phys., 13, 8365-8379, doi:10.5194/acp-13-83652013, 2013.

Putaud, J. P., Van Dingenen, R., Mangoni, M., Virkkula, A., Raes, F., Maring, H., Prospero, J. M., Swietlicki, E., Berg, O. H., Hillamo, R., and Makela, T.: Chemical mass closure and assessment of the origin of the submicron aerosol in the marine bound- ary layer and the free troposphere at Tenerife during ACE-2, Tellus B, 52, 141-168, doi:10.1034/j.1600- 0889.2000.00056.x, 2000.

Ramanathan, V. and Carmichael, G.: Global and regional climate changes due to black carbon, Nature Geosci., 1, 221-227, doi:10.1038/Ngeo156, 2008.

Reddy, M. S. and Boucher, O.: Climate impact of black carbon emitted from energy consumption in the world's regions, Geophys. Res. Lett., 34, doi:10.1029/2006g1028904, 2007.

Rolph, G. D.: Real-time Environmental Applications and Display sYstem (READY) Website, available at: http://www.ready.noaa. gov, NOAA Air Resources Laboratory, College Park, MD, 2013.

Schmid, H., Laskus, L., Abraham, H. J., Baltensperger, U., Lavanchy, V., Bizjak, M., Burba, P., Cachier, H., Crow, D., Chow, J., Gnauk, T., Even, A., ten Brink, H. M., Giesen, K. P., Hitzenberger, R., Hueglin, C., Maenhaut, W., Pio, C., Carvalho, A., Putaud, J. P., Toom-Sauntry, D., and Puxbaum, H.: Results of the "carbon conference" international aerosol carbon round robin test stage I, Atmos. Environ., 35, 2111-2121, doi:10.1016/S1352-2310(00)00493-3, 2001.

Schmidt, M. W. I. and Noack, A. G.: Black carbon in soils and sediments: Analysis, distribution, implications, and current challenges, Global Biogeochem. Cy., 14, 777-793, doi:10.1029/1999gb001208, 2008.

Shank, L. M., Howell, S., Clarke, A. D., Freitag, S., Brekhovskikh, V., Kapustin, V., McNaughton, C., Campos, T., and Wood, R.: Organic matter and non-refractory aerosol over the remote Southeast Pacific: oceanic and combustion sources, Atmos. Chem. Phys., 12, 557-576, doi:10.5194/acp-12-557-2012, 2012.

Sharma, S., Lavoue, D., Cachier, H., Barrie, L. A., and Gong, S. L.: Long-term trends of the black carbon concentrations in the Canadian Arctic, J. Geophys. Res.-Atmos., 109, D15203, doi:10.1029/2003jd004331, 2004.

Spracklen, D. V., Arnold, S. R., Sciare, J., Carslaw, K. S., and Pio, C.: Globally significant oceanic source of organic carbon aerosol, Geophys. Res. Lett., 35, doi:10.1029/2008g1033359, 2008.

Swap, R., Garstang, M., Macko, S. A., Tyson, P. D., Maenhaut, W., Artaxo, P., Kallberg, P., and Talbot, R.: The long-range transport of southern African aerosols the tropical South Atlantic, J. Geophys. Res.-Atmos., 101, 23777-23791, doi:10.1029/95jd01049, 1996.

Talbot, R. W., Harriss, R. C., Browell, E. V., Gregory, G. L., Sebacher, D. I., and Beck, S. M.: Distribution and Geochemistry of Aerosols in the Tropical North-Atlantic Troposphere - Relationship to Saharan Dust, J. Geophys. Res.-Atmos., 91, 5173-5182, doi:10.1029/Jd091id04p05173, 1996.

Verardo, D. J. and Ruddiman, W. F.: Late pleistocene charcoal in tropical Atlantic deep- sea sediments: Climatic and geochemical significance, Geology, 24, 855-857, doi:10.1130/0091-7613, 1996.

Wang, R., Tao, S., Balkanski, Y., Ciais, P., Boucher, O., Lie, J., Piao, S., Shen, H., Vuolo, M. R., Valari, M., Chen, H., Chen, Y., Cozic, A., Huang, Y., Li, B., Li, W., Shen, G., Wang, B., and Zhang, Y.: Exposure to ambient black carbon derived from a unique inventory and high resolution model, PNAS, 111, 2459-2463, doi:10.1073/pnas.1318763111, 2013

Watson, J. G., Chow, J. C., and Chen, L.-W. A.: Summary of organic and environmental carbon/black carbon analysis methods and intercomparisons, Aerosol Air Qual. Res., 5, 65-102, 2005. 
Wolff, E. W. and Cachier, H.: Concentrations and seasonal cycle of black carbon in aerosol at a coastal Antarctic station, J. Geophys. Res.-Atmos., 103, 11033-11041, doi:10.1029/97jd01363, 1998.
Zencak, Z., Elmquist, M., and Gustafsson, O.: Quantification and radiocarbon source apportionment of black carbon in atmospheric aerosols using the CTO-375 method, Atmos. Environ., 41, 7895-7906, doi:10.1016/j.atmosenv.2007.06.006, 2007. 